\title{
Mutations of PHOX2B Gene in Patients of Obesity Hypoventilation Syndrome in Central India
}

\author{
${ }^{1}$ Department of Anatomy, All India Institute of Medical Sciences \\ Bhopal, Bhopal, Madhya Pradesh, India \\ ${ }^{2}$ Department of Pulmonary Medicine, All India Institute of Medical \\ Sciences Bhopal, Bhopal, Madhya Pradesh, India \\ J Lab Physicians 2022;14:164-168.
}

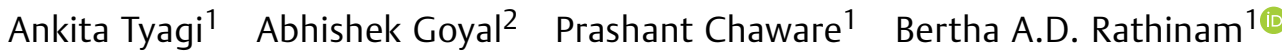

\begin{abstract}
Address for correspondence Bertha A.D. Rathinam, MS, Department of Anatomy, All India Institute of Medical Sciences Bhopal, Saket Nagar, Bhopal, 462020, India (e-mail: bertharathinam@gmail.com).
\end{abstract}

\begin{abstract}
Keywords

- obesity hypoventilation syndrome

- PHOX2B gene

Background Paired-like homeobox 2B (PHOX2B) gene on chromosome 4p12 codes for a transcription factor having a role in the formation of noradrenergic neuronal circuits. Its mutations have been linked to congenital central hypoventilation syndrome (CCHS). The clinical presentation of both, obesity hypoventilation syndrome (OHS) and CCHS in adults (named late-onset central hypoventilation syndrome), is quite similar. Because of this symptomatic similarity, multifactorial causation of OHS, the mutation of PHOX2B gene was studied in patients with OHS in this study.

Methods A hospital-based cross-sectional study was performed on patients diagnosed with OHS. The deoxyribonucleic acid was extracted from $2 \mathrm{~mL}$ of venous blood and was further amplified, specific to exon 3 . The amplified products were cast and run in $2 \%$ agarose gel and then subjected to Sanger sequencing.

Results Thirty patients of OHS ( 21 male; 9 female) were enrolled in the present study, average age being 51.7 years. The Sanger sequencing of the samples revealed no apparent areas of deletions and no apparent mutations.

Conclusion Primers for exon 3 were used for amplification in thermocycler, as exon 3 is the most frequently mutated exon for $\mathrm{PHOX} 2 \mathrm{~B}$ gene, as per existing literature. The entire gene needs to be studied for mutations and the sample size needs to be increased.
\end{abstract}

\section{Introduction}

Homeobox genes, a family of genes which help in development and differentiation of organs during the embryonic life, are located on all chromosomes. They encode transcription factors and their mutations lead to malformations and syndromes. ${ }^{1,2}$

Paired-like homeobox 2B (PHOX2B) gene, a member of this family, is located on chromosome $4 \mathrm{p} 12$ and has an exon count of 3. It codes for a transcription factor that has role in formation of neuronal circuits, especially those associated with the autonomic nervous system, mainly for the noradrenergic nerves. ${ }^{3}$ It also determines the neurotransmitter phenotype. ${ }^{4}$ Its mutations have been linked to congenital central hypoventilation syndrome (CCHS), neuroblastomas, Hirschsprung's disease, Haddad syndrome (CCHS with Hirschsprung's disease), and sudden infant death syndrome and other forms of sleep apnea. ${ }^{5}$ Pattyn et al found absence of published online September 17, 2021
DOI https://doi.org/ 10.1055/s-0041-1735582. ISSN 0974-2727. (c) 2021. The Indian Association of Laboratory Physicians. All rights reserved.

This is an open access article published by Thieme under the terms of the Creative Commons Attribution-NonDerivative-NonCommercial-License, permitting copying and reproduction so long as the original work is given appropriate credit. Contents may not be used for commercial purposes, or adapted, remixed, transformed or built upon. (https://creativecommons.org/ licenses/by-nc-nd/4.0/)

Thieme Medical and Scientific Publishers Pvt. Ltd., A-12, 2nd Floor, Sector 2, Noida-201301 UP, India 
motor neuron differentiation in mice with knocked out PHOX2B gene. The precursor cells for these motor neurons underwent early apoptosis and those which migrated showed absence of postmitotic markers, thus making them physiologically ineffective. This shows that PHOX2B gene is responsible for formation of all visceral and branchial motor neurons in the hindbrain. ${ }^{6}$

The earliest description of hypoventilation and apnea caused by PHOX2B mutation was described in 1970 as Ondine's curse or CCHS. ${ }^{7}$ PHOX2B mutation in CCHS leads to addition of extra alanine residues to the poly A tail causing abnormalities in differentiation of neurons, especially those of the autonomic nervous system. As a result of this, there is inefficient regulation of respiration and other autonomic functions, known as autonomic nervous system dysregulation. $^{8}$

Obesity Hypoventilation Syndrome (OHS) is a severe condition characterized by the presence of hypoxemia and hypercapnia along with daytime sleepiness in a person with a body mass index (BMI) of more than or equal to $30 \mathrm{~kg} / \mathrm{m}^{2}$, unexplained by other systemic causes like severe hypothyroidism, obstructive, or restrictive pulmonary diseases. ${ }^{9,10}$ OHS has a complex pathophysiology, with several factors that seem to have interplay in its causation. Approximately $90 \%$ of patients with OHS is associated with obstructive sleep apnea (OSA). Patients with OHS are usually at the extreme end of the spectrum of OSA. ${ }^{11}$ The prevalence of OHS seems to increase with increase in the BMI of the individual, with a prevalence of 10 to $20 \%$ in individuals with BMI of over $50 \mathrm{~kg} / \mathrm{m}^{2}{ }^{10,12}$ Apart from obesity, there are other more complex entities like leptin resistance and blunting of the central respiratory drive at play in development of OHS. ${ }^{13-15}$ Patients with OHS more likely to have type II diabetes mellitus, systemic hypertension, and cardiovascular disease. $^{10,16}$

Recently, the involvement of neural factors in the ventilatory control and their role in the persistence of hypercapnia in the waking state have been studied. ${ }^{11,17}$ Respiratory regulation in response to hypercapnia is impaired in patients of OHS. Disorder of ventilatory control and alveolar hypoventilation together contributes to inability of such individuals to return to a eucapnic state after hypercapnia. ${ }^{18}$ The manifestation of neural "dysregulation" in this condition is quite similar to that seen in another disease, known as the CCHS. This rare condition is almost exclusively seen due to the mutation of the PHOX2B gene, with just a few hundred cases reported worldwide. CCHS, per se, is seen more commonly in children and such children present with hypoxemia, hypercapnia, and daytime somnolence. Children suffering from this disorder may often have syndromes or conditions associated with this gene's mutation and many do not survive childhood. ${ }^{19} \mathrm{~A}$ milder form is late-onset central hypoventilation syndrome (LOCHS), which usually begins in teenage or early adulthood and its manifestation is often limited, not exclusively, however, to that of the respiratory system in the form of sleep apnea. ${ }^{20}$ The clinical presentation of both OHS and CCHS in adults (named LOCHS) is quite similar. Because of this symptomatic similarity, multifactorial causation of OHS, the mutation of PHOX2B gene, was studied in patients with OHS in this study. Till date, no study has been conducted to determine the correlation between OHS and PHOX2B gene, therefore, in the present study, the existing research on CCHS and LOCHS with their gene mutation loci were taken as reference.

\section{Aims and Objectives}

This article aims to determine the association between mutations of PHOX2B gene in patients of OHS.

\section{Materials and Methods}

\section{Study Design}

The present study was a hospital-based cross-sectional study. All patients diagnosed as OHS ( $>18$ years) in a tertiary care center in Central India were chosen for the study. The study was conducted from December 2017 to June 2019.

OHS was defined as:

1. $\mathrm{BMI}>30 \mathrm{~kg} / \mathrm{m}^{2}$.

2. $\mathrm{PaCO} 245 \mathrm{~mm} \mathrm{Hg}$.

3. Absence of other causes like hypothyroidism or obstructive/restrictive lung disease.

Institutional Human Ethical Clearance was obtained (via letter number IHEC-LOP/2017/MD003) prior to the start of the study and 33 patients were enrolled. Written and informed consent was obtained from all subjects at the time of enrollment. Note that $2 \mathrm{~mL}$ of venous blood was drawn into an ethylenediaminetetraacetic acid vial, taking all aseptic precautions. This was subjected to deoxyribonucleic acid (DNA) extraction using Spin Protocol by Qiagen. The DNA was then amplified in a 96-well thermocycler. Primer sequences of exon 3 were utilized in the amplification, as this exon was reported to be the most common site for mutations in CCHS.

The primers used were as follows:

\section{Forward primer: ACCCTAACCGGTGCTTTTCT Reverse primer: AGCGCGATTACTTTAGGCCC}

Polymerase chain reaction (PCR) reaction mixture for exon 3 of PHOX2b gene was as follows:

\begin{tabular}{|l|l|l|l|l|l|l|}
\hline Reagent & $\begin{array}{l}\text { Extracted } \\
\text { DNA }\end{array}$ & $\begin{array}{l}\text { Forward } \\
\text { primer }\end{array}$ & $\begin{array}{l}\text { Reverse } \\
\text { primer }\end{array}$ & $\begin{array}{l}\text { Hot } \\
\text { Taq } \\
\text { Master } \\
\text { Mix }\end{array}$ & $\begin{array}{l}\text { Nuclease } \\
\text { free } \\
\text { water }\end{array}$ & Total \\
\hline $\begin{array}{l}\text { Concen- } \\
\text { tration }\end{array}$ & $\begin{array}{l}100- \\
250 \mathrm{ng}\end{array}$ & $0.2 \mu \mathrm{M}$ & $0.2 \mu \mathrm{M}$ & $1 \mathrm{X}$ & - & - \\
\hline Volume & $5 \mu \mathrm{L}$ & $1 \mu \mathrm{L}$ & $1 \mu \mathrm{L}$ & $25 \mu \mathrm{L}$ & $18 \mu \mathrm{L}$ & $50 \mu \mathrm{L}$ \\
\hline
\end{tabular}

The amplification protocol used was as follows:

\begin{tabular}{|l|l|l|l|l|l|}
\hline $\begin{array}{l}\text { Initial } \\
\text { denaturation }\end{array}$ & \multicolumn{2}{|l|}{30 cycles } & $\begin{array}{l}\text { Final } \\
\text { extension }\end{array}$ & Hold \\
\hline \begin{tabular}{l|l|l|l|}
$95^{\circ} \mathrm{C}$ for \\
5 minutes
\end{tabular} & Denaturation & Annealing & Extension & $\begin{array}{l}72^{\circ} \mathrm{C} \text { for } \\
7 \text { minutes }\end{array}$ & $4^{\circ} \mathrm{C}$ \\
\cline { 2 - 5 } & $95^{\circ} \mathrm{C}$ for \\
45 seconds & $\begin{array}{l}59^{\circ} \mathrm{C} \text { for } \\
45 \text { seconds }\end{array}$ & $\begin{array}{l}72^{\circ} \mathrm{C} \text { for } \\
1 \text { minutes }\end{array}$ & & \\
& & & & \\
\hline
\end{tabular}




\section{Working Protocol for DNA Amplification}

The amplified products were subjected to agarose gel electrophoresis on $2 \%$ agarose gel. The separated bands on the gel were purified using QIAquick Gel Extraction Kit. The purified DNA samples were subjected to Sanger sequencing, following which, they were subjected to sequence alignment using the software Clustal Omega (Courtesy of the European Bioinformatics Institute [EMBL-EBI]).

\section{Results}

In the present study, 33 patients of OHS, who attend the Pulmonary Medicine Outpatient Department, All India Institute of Medical Sciences Bhopal (AIIMS Bhopal), Bhopal, Madhya Pradesh, India, were enrolled. Three patients, after initial enrolment, dropped out of the study. Thirty patients (21 male; 9 female) were enrolled in the present study. The average age of the study subjects was 51.7 years (range: 36-72 years).

Mean BMI of the study subjects was 37.43 (range: 30.251.6) and the standard deviation was 7.37 (-Table 1). The other baseline characteristics are tabulated in - Tables 2 and 3.
After extracting the DNA using QIAGEN's Spin Protocol from blood and body fluids and after amplification of the desired segment of the gene using PCR, the samples were subjected to gel electrophoresis on $2 \%$ agarose gel. A healthy control was used along with the patients' samples. Amplification of the targeted area was confirmed in all the samples. The amplified product produced a band between 700 to 800 base pairs corresponding to the DNA ladder.

The size of the PCR product was 736 base pairs. As a result of this, the prominent band between 700 and 800 base pairs on the agarose gel was taken to be the band of interest.

The Sanger sequencing of the samples revealed no apparent areas of deletions and no apparent mutations (- Fig. 1).

None of the samples showed insertion of multiple repeats of alanine within the sequence, and there were no areas of deletion or insertion of other base pairs. The samples did not show any frameshift or point mutations on alignment.

\section{Discussion}

In 2004, Matera et $\mathrm{al}^{21}$ conducted a study on 27 patients of CCHS, which included 3 patients of LOCHS and sequenced all three exons of PHOX2B gene. They noted the presence of

Table 1 Subject distribution according to baseline characteristics

\begin{tabular}{|l|l|l|l|l|l|l|l|l|l|l|l|l|l|}
\hline \multicolumn{9}{|l|}{ Age (y) } & \multicolumn{3}{l|}{ Sex } & \multicolumn{3}{l|}{ Body mass index (BMI) $\left(\mathrm{kg} / \mathrm{m}^{2}\right)$} \\
\hline $\mathbf{3 0 - 4 0}$ & $\mathbf{4 1 - 5 0}$ & $\mathbf{5 1 - 6 0}$ & $\mathbf{6 1 - 7 0}$ & $>\mathbf{7 0}$ & Male & Female & $\begin{array}{l}\mathbf{1 8 . 5 -} \\
\mathbf{2 4 . 9}\end{array}$ & $\begin{array}{l}\mathbf{2 5 . 0 -} \\
\mathbf{2 9 . 9}\end{array}$ & $\begin{array}{l}30.0- \\
\mathbf{3 5 . 9}\end{array}$ & $\begin{array}{l}36.0- \\
\mathbf{4 0 . 0}\end{array}$ & $\begin{array}{l}40.0- \\
\mathbf{4 5 . 9}\end{array}$ & $\begin{array}{l}46.0- \\
50.0\end{array}$ & $>\mathbf{5 0 . 0}$ \\
\hline 3 & 11 & 10 & 5 & 1 & 21 & 9 & 2 & 4 & 10 & 7 & 5 & 1 & 1 \\
\hline
\end{tabular}

Table 2 Subject distribution according to examination and blood investigations

\begin{tabular}{|l|l|l|l|l|l|l|}
\hline \multicolumn{3}{|l|}{ Blood pressure (mm Hg) } & \multicolumn{3}{l|}{ Hemoglobin A1c (HbA1c) } \\
\hline Normotensive & Prehypertensive & $\begin{array}{l}\text { Grade 1 } \\
\text { hypertension }\end{array}$ & $\begin{array}{l}\text { Grade 2 } \\
\text { hypertension }\end{array}$ & $\begin{array}{l}\text { Normal } \\
(<6.0 \%)\end{array}$ & $\begin{array}{l}\text { Prediabetic } \\
(6.0-6.4 \%)\end{array}$ & $\begin{array}{l}\text { Diabetic } \\
(>6.5 \%)\end{array}$ \\
\hline 11 & 7 & 6 & 6 & 11 & 1 & 18 \\
\hline
\end{tabular}

Table 3 Subject distribution according to arterial blood gas (ABG) analysis values

\begin{tabular}{|l|l|l|l|l|l|l|l|}
\hline & \multicolumn{2}{|l|}{ PaCO2 $(\mathrm{mm} \mathrm{Hg})$} & \multicolumn{3}{l|}{ HCO3 (mEq/L) } \\
\hline ABG values & $25-30$ & $31-35$ & $36-40$ & $>40$ & $15-20$ & $21-25$ & $26-30$ \\
\hline Number of patients & 2 & 10 & 15 & 3 & 10 & 16 & 4 \\
\hline
\end{tabular}

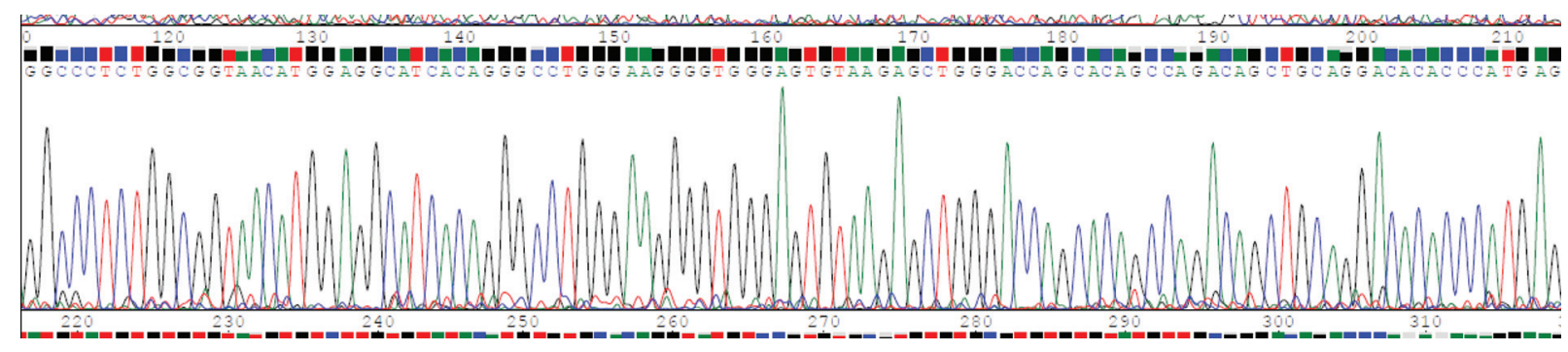

Fig. 1 Sanger sequence of patient ID OS - 13 showing base pairs 100 to 210 . 
three different kinds of mutations, all on exon 3. Exon 3 is the most common out of all three exons where mutations have been reported by previous workers. They noted deletion of $C$ at position 614 to 618 and insertion of $G$ at position 862 to 866 in 2 patients. They also reported deletion of codons from position 721 to 756 of the exon. In the present study, no mutations were observed at these specific loci on exon 3 in patients with OHS.

Studies were performed on CCHS by two independent teams of scientists, Sasaki et $\mathrm{al}^{22}$ and Weese-Mayer et al. Sasaki et al studied 7 patients and observed frameshift mutations and polyalanine repeat mutations (PARM) in them. No such corresponding mutations at any position were found in the present study.

Weese-Mayer et al studied 67 patients of CCHS and compared them to a control group. They investigated a plethora of genes responsible for autonomic nervous system growth and differentiation. They observed that 65 out of these 67 patients had PARM on exon 3. One patient had a nonsense mutation and the other had no mutation but was suffering from respiratory complications as the others. ${ }^{8}$ No such corresponding mutations were identified in the present study.

Some of the other genes involved in the causation of OSA, indirectly, are those coding for neuropeptide $\mathrm{Y}$ and peroxisome proliferator-activated receptor gamma (PPAR $\gamma$ ). These genes are believed to promote excessive accumulation of fat, increasing the chances for developing the mechanical problems of respiration due to obesity and eventually, OSA and OHS. In 2011, Bhushan et al studied these genes in 142 Indians with OSA and 110 without. They found a higher frequency of a variant allele of the PPAR $\gamma$ gene in persons who were suffering from sleep apnea. ${ }^{23}$ In the next year, that is, in 2012, Lingappa et al detected a neonate who showed PARM in the form of 10 polyalanine repeats, making her the first confirmed case of PHOX2B gene mutation from India. ${ }^{24}$ In the present study we did not observe any PARM.

Limitations of these studies were small sample size from a single center. Due to restriction of funds, the current tests employed for the PHOX2B gene were performed only on exon 3 , based on results of previous studies. This, however, does not account for mutations in exons 1 and 2, nor does it account for mutations of the intron regions or splicing mutations.

This is probably the first study done to find out the genetic association between PHOX2B gene and OHS. We did not find any genetic association between these two.

\section{Funding}

The authors gratefully acknowledge the Indian Council of Medical Research for funding the present study in the form of a grant for MD Dissertation.

\section{Conflict of Interest}

The authors declare no conflict of interest.

Acknowledgments

We thank Professor Sarman Singh, Director, All India Institute of Medical Sciences, Bhopal, all the teaching and non-teaching staff of the Departments of Anatomy and Pulmonary Medicine, and all patients of OHS who agreed to participate in the study.

\section{References}

1 Dollé P, Duboule D. Structural and functional aspects of mammalian Hox genes. Adv Dev Biochem 1993;2:57-109

2 Pattyn A. Phox2b and motoneuronal differentiation [Internet]. 2000. Accessed June 11, 2019 at: https://dev.biologists.org/content/develop/127/7/1349.full.pdf

3 Amiel J, Laudier B, Attié-Bitach T, et al. HT-N, 2003 undefined. Polyalanine expansion and frameshift mutations of the pairedlike homeobox gene PHOX2B in congenital central hypoventilation syndrome. nature.com [Internet]. Accessed June 11, 2019 at: https://www.nature.com/articles/ng1130.

4 Betancur P, Bronner-Fraser M, Sauka-Spengler T. Assembling neural crest regulatory circuits into a gene regulatory network. Annu Rev Cell Dev Biol 2010;26:581-603

5 Tanizawa K, Chin K. Genetic factors in sleep-disordered breathing. Respir Investig 2018;56(02):111-119

6 Pattyn A, Hirsch M, Goridis C, Brunet JF. Control of hindbrain motor neuron differentiation by the homeobox gene Phox $2 \mathrm{~b}$. Development 2000;127(07):1349-1358

7 Mellins RB, Balfour HH Jr, Turino GM, Winters RW. Failure of automatic control of ventilation (Ondine's curse). Report of an infant born with this syndrome and review of the literature. Medicine (Baltimore) 1970;49(06):487-504

8 Weese-Mayer DE, Berry-Kravis EM, Zhou L, et al. Idiopathic congenital central hypoventilation syndrome: analysis of genes pertinent to early autonomic nervous system embryologic development and identification of mutations in PHOX2b. Am J Med Genet A 2003;123A(03):267-278

9 Piper AJ, Grunstein RR. Obesity hypoventilation syndrome: mechanisms and management. Am J Respir Crit Care Med 2011;183 (03):292-298

10 Mokhlesi B, Tulaimat A, Faibussowitsch I, Wang Y, Evans AT. Obesity hypoventilation syndrome: prevalence and predictors in patients with obstructive sleep apnea. Sleep Breath 2007;11 (02):117-124

11 Mokhlesi B, Kryger MH, Grunstein RR. Assessment and management of patients with obesity hypoventilation syndrome. Proc Am Thorac Soc 2008;5(02):218-225

12 Kessler R, Chaouat A, Schinkewitch P, et al. The obesity-hypoventilation syndrome revisited: a prospective study of 34 consecutive cases. Chest 2001;120(02):369-376

13 Phipps PR, Starritt E, Caterson I, Grunstein RR. Association of serum leptin with hypoventilation in human obesity. Thorax 2002;57(01):75-76

14 Mokhlesi B. Obesity hypoventilation syndrome: a state-of-the-art review. Respir Care 2010;55(10):1347-1362, discussion 13631365

15 Norman RG, Goldring RM, Clain JM, et al. Transition from acute to chronic hypercapnia in patients with periodic breathing: predictions from a computer model. J Appl Physiol (1985) 2006;100(05): 1733-1741

16 Goyal A, Pakhare A, Tiwari IR, Khurana A, Chaudhary P. Diagnosing obstructive sleep apnea patients with isolated nocturnal hypoventilation and defining obesity hypoventilation syndrome using new European Respiratory Society classification criteria: an Indian perspective. Sleep Med 2020;66:85-91

17 Sampson MG, Grassino K. Neuromechanical properties in obese patients during carbon dioxide rebreathing. Am J Med 1983;75 (01):81-90

18 Zwillich CW, Sutton FD, Pierson DJ, Greagh EM, Weil JV. Decreased hypoxic ventilatory drive in the obesity-hypoventilation syndrome. Am J Med 1975;59(03):343-348 
19 Hammel M, Klein M, Trips T, Priessmann H, Ankermann T, Holzinger A. Congenital Central Hypoventilation Syndrome due to PHOX2b gene defects: inheritance from asymptomatic parents. Klin Padiatr 2009;221(05):286-289

20 Doherty LS, Kiely JL, Deegan PC, et al. Late-onset central hypoventilation syndrome: a family genetic study. Eur Respir J 2007;29(02):312-316

21 Matera I, Bachetti T, Puppo F, Di Duca M, Morandi F, Casiraghi GM, Cilio MR, Hennekam R, Hofstra R, Schöber JG, Ravazzolo R, Ottonello $\mathrm{G}$, Ceccherini I. PHOX2B mutations and polyalanine expansions correlate with the severity of the respiratory phenotype and associated symptoms in both congenital and late onset Central Hypoventilation syndrome. J Med Genet 2004;41(05):373-380
22 Sasaki A, Kanai M, Kijima K, Akaba K, Hashimoto M, Hasegawa H, Otaki S, Koizumi T, Kusuda S, Ogawa Y, Tuchiya K, Yamamoto W, Nakamura T, Hayasaka K. Molecular analysis of congenital central hypoventilation syndrome. Hum Genet 2003;114(01): 22-26

23 Bhushan B, Guleria R, Misra A, Luthra K, Kumar G. Association of PPARY2 (Pro12Ala) and neuropeptide Y (Leu7Pro) gene polymorphisms with obstructive sleep apnea in obese Asian Indians. Dis Markers 2011;30(01):31-38

24 Lingappa L, Panigrahi NK, Chirla DK, Burton-Jones S, Williams MM. Congenital central hypoventilation syndrome with PHOX2B gene mutation. Indian J Pediatr 2012;79(11):1526-1528[Internet] 